\title{
Effect of Cell Wall Ductility and Toughness on Compressive Response and Strain Rate Sensitivity of Aluminium Foam
}

\author{
Alexandra Byakova $\mathbb{D}^{1},{ }^{1}$ Svyatoslav Gnyloskurenko ${ }^{(D)},^{2}$ Andrey Vlasov $\mathbb{D}^{1}{ }^{1}$ \\ Nikolay Semenov, ${ }^{1}$ Yan Yevych, ${ }^{1}$ Oleksandra Zatsarna, ${ }^{3}$ and Vladimir Danilyuk ${ }^{4}$ \\ ${ }^{1}$ Institute for Problems of Materials Science, National Academy of Sciences of Ukraine, 3 Krzhyzhanovsky St., Kiev 03142, Ukraine \\ ${ }^{2}$ Physical-Technological Institute of Metals and Alloys, National Academy of Sciences of Ukraine, 34/1 Vernadsky Ave., \\ Kiev 03142, Ukraine \\ ${ }^{3}$ Institute for Metal Physics, National Academy of Sciences of Ukraine, 36 Vernadsky Ave., Kiev 03680, Ukraine \\ ${ }^{4}$ Institute for Problems of Strength, National Academy of Sciences of Ukraine, 2 Timiryazevs'ka str., Kiev 01014, Ukraine \\ Correspondence should be addressed to Svyatoslav Gnyloskurenko; slava.vgn@gmail.com
}

Received 9 December 2018; Revised 27 February 2019; Accepted 26 March 2019; Published 2 May 2019

Academic Editor: Daniela Pilone

Copyright (C) 2019 Alexandra Byakova et al. This is an open access article distributed under the Creative Commons Attribution License, which permits unrestricted use, distribution, and reproduction in any medium, provided the original work is properly cited.

\begin{abstract}
The study presents the effect of cell wall ductility and toughness on the compressive behaviour of closed-cell Al foams under static and dynamic loading and localised deformation by indentation. Two kinds of $\mathrm{Al}$ alloys including relatively ductile $\mathrm{AlSiMg}$ alloy and high-strength AlZnMg alloy, which comprises a great amount of brittle eutectic domains, were used as matrix materials. Both kinds of $\mathrm{Al}$ foams were fabricated via newly developed melt processing using the $\mathrm{CaCO}_{3}$-foaming agent without Ca additive. Mechanical behaviour of $\mathrm{Al}$ foams under quasi-static compression and indentation was examined and compared with that performed under dynamic loading using direct impact tests. Characteristic events revealed in deformation patterns of Al foams at quasi-static compression were also monitored with the CCD camera. Significant differences in stress-strain response and strain rate sensitivity of $\mathrm{Al}$ foams arose from the difference in the microstructure, and hence, ductility and toughness of the cell wall material were investigated and discussed.
\end{abstract}

\section{Introduction}

Closed-cell aluminium foams offer high structural efficiency of the multifunctional material attractive for engineering applications where combination of low weight and novel physical and mechanical properties is required $[1,2]$. Excellent combination of mechanical, acoustic, electrical, and thermal properties makes $\mathrm{Al}$ foam an ideal material for the usage as lightweight construction in building and housing for more diversified lifestyle by sound absorbing [3, 4], electromagnetic shielding [5], thermal insulation [6], fire protection [7], and blast-induced damage [8] as well as in transport and particularly, in automotive and aerospace industries $[2,7]$ and shipbuilding structures $[2,9,10]$. It is important that $\mathrm{Al}$ foams demonstrate excellent capability to absorb considerable impact energy by progressive deformation at almost constant nominal stress, making them of growing interest for packaging and utilizing as energy absorbers and crash barriers $[1,2,7,8]$. Moreover, $\mathrm{Al}$ foams are efficient in design of weight-sensitive sandwich panels $[11,12]$ and crashworthy structures such as integral metal/ ceramic/glass fibre composites used against impact and, especially, the ballistic one to defend terrestrial and marine vehicles for which safety at the collision and crash accident are of increased importance $[7,13]$. Attention is paid to the fact that $\mathrm{Al}$ foams as structural components can drastically reduce the damage caused by explosion and/or blast loading, as it has been demonstrated by field experiments and numerical studies [14]. In view of this, mechanical response of laminated composites and sandwich panels with $\mathrm{Al}$ foam core being subjected to impact and blast loading has become a topic of growing interest. Starting with 2000, a number of experimental and numerical studies related to the matter of issue were reported in literature [15-20]. In addition, papers 
related to mechanical response of $\mathrm{Al}$ foams subjected to localized loading by indentation at the different velocities [21-24] and elevated temperature [25] are considered to be of special attention. The results of these studies are very useful for understanding the damage of $\mathrm{Al}$ foam core under impact by debris resulting from a blast.

Presently, there is a strong motivation for a search of high-quality foamed material to perform it in the most favourable design of engineering construction and, particularly, crashworthy structures. At this point, detailed knowledge regarding the compressive response of $\mathrm{Al}$ foams subjected to different loading conditions and limits of foaming processes is important to achieve an efficient balance between utilization of impact energy and capital/ material cost. Although a variety of alternative foaming processes were developed last decade [26], the research concerning compressive response of $\mathrm{Al}$ foams is mainly concentrated on those fabricated by currently employed production methods. Generally, there are three familiar methods currently employed for mass production, i.e., gas injection into a melt with ceramic particles, melt processing, and powder compact technique [2]. It is noticeable that the last two processes used in industrial production are usually performed with $\mathrm{TiH} 2$ as the foaming agent. However, each method is characterized by one or another disadvantages. In particular, hardly machining of $\mathrm{Al}$ foam caused by great fraction volume of ceramic particles presented in the metal matrix alloy and high capital cost are indicative of the gas injection method. Essential economical limitation for melt processing and powder compact technique arises from employing costly additives such as titanium hydride $\left(\mathrm{TiH}_{2}\right)$ and also granulated $\mathrm{Ca}$ as the melt thickening agent. These additives influence significantly the compressive response of $\mathrm{Al}$ foams owing to contamination of the cell wall material by undesirable low ductile and brittle side products formed in the course of the foaming process [27, 28]. From this point of view, applications of cheap calcium carbonate $\left(\mathrm{CaCO}_{3}\right)$ as the alternative foaming agent [29] offers indisputable advantages compared to currently employed titanium hydride $\left(\mathrm{TiH}_{2}\right)$. Unfortunately, the efforts intended to the development and improvement of the processing routes with calcium carbonate $\left(\mathrm{CaCO}_{3}\right)$ are few in number [30-34].

During the last decades, mechanical response of $\mathrm{Al}$ foams under static and dynamic compression has been in focus of many researches employed in scientific and engineering applications. In particular, mechanical behaviour and properties of $\mathrm{Al}$ foams subjected to static loading and performed by different foaming methods and techniques have been summarized in [35], while experimental analysis of deformation mechanisms in closed-cell $\mathrm{Al}$ foams of different compositions was done in $[36,37]$. In addition, effect of the cell wall microstructure on the deformation and fracture of $\mathrm{Al}$ foams fabricated in line with melt processing Alporas-like route with different foaming agents was reported in $[21,27]$. Some information related to the effect of radial constraint loading that is crucial for designing the components filled by $\mathrm{Al}$ foam is currently available [38]. Difference in quasi-static and dynamic compressive properties of closed-cell $\mathrm{Al}$ foams was reported and specified although the efforts were mainly concentrated on those performed by currently employed forming methods mentioned above. High strain rate compressive behaviour of $\mathrm{Al}$ foam was comprehensively investigated in $[39,40]$ and also evaluated in [41]. The results of dynamic and quasi-static compression tests were also reported in $[42,43]$. Moreover, response of closed-cell $\mathrm{Al}$ foam under static and impact loading was compared and analyzed in the experimental investigations [44, 45] and numerical studies [46, 47]. In addition, mechanisms of cell collapse of the composites based on the $\mathrm{Al}$ alloy foam under static and dynamic loading conditions were presented in [48].

As to the matter at this issue, the important point is whether $\mathrm{Al}$ foams demonstrate strain rate sensitivity. This is especially essential since current misinterpretations may lead to improper designing of the crashworthy structures with $\mathrm{Al}$ foam core. Currently available experimental results related to strain rate sensitivity of the closed-cell $\mathrm{Al}$ foams and performed by different foaming methods and techniques are listed in Table 1.

By comparing the collected results, it could be assumed that the reason of a different strain rate sensitivity of $\mathrm{Al}$ foams in not completely clear. The results reported in literature are controversial to some extension and even conflicting in many cases. Indeed, it is not easy to give a universal explanation for strain rate sensitivity of Al foams since they are usually performed by different manufacturing processes. Actually, nonhomogeneous distribution of density throughout the foamed material [37,61], cell morphology (size and shape) [62, 63], cell wall geometry [64], and imperfection of the cellular structure [65] as well as different strengths of the matrix alloy, which is additionally affected by the dispersed particles such as $\mathrm{Al}_{2} \mathrm{O}_{3}, \mathrm{CaO}, \mathrm{SiC}$, CaTiAl, and $\mathrm{Al}_{3} \mathrm{Ti}[54,66]$, can lead to some uncertainty in reliable determination of the mechanical response for different kinds of $\mathrm{Al}$ foams. Therefore, misunderstanding the experimental findings done in the different studies might be greatly caused by the differences in the cellular structure and, hence, micromechanism of deformation of $\mathrm{Al}$ foams. Moreover, dynamic response of $\mathrm{Al}$ foam is also affected by apparatus arrangement and test conditions, as evidenced from Table 1. Standard split Hopkinson pressure bars (SHPB) or direct impact tests are usually employed for dynamic tests. However, the standard split Hopkinson pressure bar (SHPB) test method is presently considered to be weakly adequate under dynamical loading since requirements concerning homogeneous deformation cannot be perfectly ensured [46]. This also might result in misunderstanding the experimental findings determined by using SHPB set up. Therefore, improved test methods named direct-impact Hopkinson pressure bar (DHPB) and direct tension-compression Hopkinson bar (DTCHB) have been recently designed and used in the experiments $[54,60]$. In addition, differences in rate sensitivity of $\mathrm{Al}$ foams are presently ascribed to the influence of two phenomena, i.e., strain rate dependence and microinertial effects. The origin of the above phenomena was found to be dependent on the impact velocity. Three deformation modes corresponding to different velocities were originally found and 
TABLE 1: Strain rate sensitivity of closed-cell Al foams.

\begin{tabular}{|c|c|c|c|c|c|c|}
\hline $\begin{array}{l}\text { Foam } \\
\text { supplier }\end{array}$ & $\begin{array}{l}\text { Processing } \\
\text { method }\end{array}$ & $\begin{array}{l}\text { Matrix alloy and } \\
\text { processing additives }\end{array}$ & $\begin{array}{l}\text { Relative density }\left(\rho / \rho_{s}\right)^{1} \\
(\text { cell size, } \mathrm{mm})\end{array}$ & $\begin{array}{l}\text { Test method: strain } \\
\text { rate }\left(\mathrm{s}^{-1}\right)\end{array}$ & Sensitivity & References \\
\hline Alporas $^{\mathrm{TM}}$ & Melt route & $\begin{array}{c}\mathrm{Al} \\
\mathrm{Ca}+\mathrm{TiH}_{2}\end{array}$ & $0.10(4.5)$ & Direct impact, $10^{-5}-10^{1}$ & Sensitive & {$[24]$} \\
\hline Alporas $^{\mathrm{TM}}$ & Melt route & $\begin{array}{c}\mathrm{Al} \\
\mathrm{Ca}+\mathrm{TiH}_{2}\end{array}$ & $0.07 / 0.15(\sim 2-7)$ & $\mathrm{SHPB}^{2}, 10^{2}-10^{3}$ & Sensitive & {$[40]$} \\
\hline Alporas $^{\mathrm{TM}}$ & Melt route & $\begin{array}{c}\mathrm{Al} \\
\mathrm{Ca}+\mathrm{TiH}_{2}\end{array}$ & $0.1(2.6)$ & $\mathrm{SHPB}^{2}, 10^{-3}-9 \times 10^{2}$ & Sensitive & {$[41]$} \\
\hline Alporas $^{\mathrm{TM}}$ & Melt route & $\begin{array}{c}\mathrm{Al} \\
\mathrm{Ca}+\mathrm{TiH}_{2}\end{array}$ & $0.08-0.10(4-5)$ & Compression $10^{-5}-10^{-1}$ & Sensitive & {$[49]$} \\
\hline Alporas $^{\mathrm{TM}}$ & Melt route & $\begin{array}{c}\mathrm{Al} \\
\mathrm{Ca}+\mathrm{TiH}_{2}\end{array}$ & $0.10(2.6)$ & $\mathrm{SHPB}^{2}, 10^{-3}-10^{3}$ & Sensitive & {$[50]$} \\
\hline Alporas $^{\mathrm{TM}}$ & Melt route & $\begin{array}{c}\mathrm{Al} \\
\mathrm{Ca}+\mathrm{TiH}_{2}\end{array}$ & $0.08(\sim 3.0)$ & $\mathrm{SHPB}^{2}, 10^{-3}-10^{3}$ & Sensitive & {$[51,52]$} \\
\hline Alporas $^{\mathrm{TM}}$ & Melt route & $\begin{array}{c}\mathrm{Al} \\
\mathrm{Ca}+\mathrm{TiH}_{2}\end{array}$ & $0.06-0.25(4.5)$ & $\begin{array}{l}\text { SHPB }^{2} \text {, drop weight } \\
\text { impact, } 10^{-3}-10^{3}\end{array}$ & Sensitive & {$[53]$} \\
\hline $\mathrm{MCM}^{*}$ & Melt route & $\begin{array}{c}\text { Al- } 4.82 \mathrm{Ni}-3.06 \mathrm{Mg}-7.19 \\
\text { others } \\
\mathrm{TiH}_{2}\end{array}$ & $0.12(3)$ & $\mathrm{DHPB}^{3}, 10^{-3}-10^{3}$ & Sensitive & {$[54]$} \\
\hline Alporas $^{\mathrm{TM}}$ & Melt route & $\begin{array}{c}\mathrm{Al}-7 \mathrm{Zn}-0.5 \mathrm{Mg} \\
\mathrm{Ca}+\mathrm{TiH}_{2}\end{array}$ & $0.06(3.0-4.5)$ & $\mathrm{SHPB}^{2}, 10^{-3}-10^{2}$ & Insensitive & {$[55]$} \\
\hline Alporas $^{\mathrm{TM}}$ & Melt route & $\begin{array}{c}\mathrm{Al}-7 \mathrm{Zn}-0.5 \mathrm{Mg} \\
\mathrm{Ca}+\mathrm{TiH}_{2}\end{array}$ & $0.06(3.0-4.5)$ & $\begin{array}{l}\text { Drop weight impact, } \\
10^{-3}-10^{2}\end{array}$ & Insensitive & {$[56]$} \\
\hline Alporas $^{\mathrm{TM}}$ & Melt route & $\begin{array}{c}\text { Al-5Zn-1Mg; Al-7Zn- } \\
0.5 \mathrm{Mg} \\
\mathrm{Ca}+\mathrm{TiH}_{2}\end{array}$ & $0.06-0.16(2.4-3.7)$ & $\begin{array}{l}\text { Drop weight impact, } \\
10^{-3}-10^{2}\end{array}$ & Insensitive & {$[57]$} \\
\hline Alulight $^{\mathrm{TM}}$ & $\begin{array}{l}\text { Powder } \\
\text { technique }\end{array}$ & $\begin{array}{c}\mathrm{Al}-0.6 \mathrm{Mg}-0.3 \mathrm{Si} \\
\mathrm{TiH}_{2}\end{array}$ & $0.16-0.40(\sim 1)$ & $\begin{array}{c}\mathrm{SHPB}^{2} \text {, direct impact, } \\
\qquad 10^{-3}-10^{3}\end{array}$ & Insensitive & {$[39]$} \\
\hline IFAM & $\begin{array}{l}\text { Powder } \\
\text { technique }\end{array}$ & $\begin{array}{c}\mathrm{Al}-0.6 \mathrm{Mg}-0.3 \mathrm{Si} \\
\mathrm{TiH}_{2}\end{array}$ & $0.23(5)$ & $\mathrm{SHPB}^{2}, \mathrm{DHPB}^{3}$ & Sensitive & {$[58]$} \\
\hline Shunk ${ }^{\mathrm{TM}}$ & $\begin{array}{l}\text { Powder } \\
\text { technique }\end{array}$ & $\begin{array}{c}\mathrm{Al}-7 \mathrm{Si} \\
\mathrm{TiH}_{2}\end{array}$ & $0.07-0.24(1.08-2.82)$ & Drop weight, $10^{-3}-10^{2}$ & Sensitive & {$[59]$} \\
\hline IFAM & $\begin{array}{l}\text { Powder } \\
\text { technique }\end{array}$ & $\begin{array}{c}\mathrm{Al}-7 \mathrm{Si} \\
\mathrm{TiH}_{2}\end{array}$ & $0.27-0.40(4 / 14)$ & $\mathrm{DTCHB}^{4}, 10^{-3}-6 \times 10^{2}$ & $\begin{array}{l}\text { Slightly sensitive/ } \\
\text { Insensitive }\end{array}$ & {$[60]$} \\
\hline Alulight ${ }^{\mathrm{TM}}$ & $\begin{array}{l}\text { Powder } \\
\text { technique }\end{array}$ & $\begin{array}{c}\text { Al-12Si-0.6Mg } \\
\mathrm{TiH}_{2}\end{array}$ & $0.13-0.20(4.5)$ & Drop weight impact & Slightly sensitive & {$[43]$} \\
\hline $\begin{array}{l}\text { Hydro/ } \\
\text { Cymat }^{\mathrm{TM}}\end{array}$ & $\begin{array}{l}\text { Gas } \\
\text { injection }\end{array}$ & $\begin{array}{c}\mathrm{Al}-(7-9) \mathrm{Si}-(0.5-1) \mathrm{Mg} \\
\mathrm{SiC}\end{array}$ & $0.04-0.19(4 / 14)$ & $\begin{array}{l}\mathrm{SHPB}^{2}, 10^{2}-10^{4} \text {, direct } \\
\quad \text { impact, } 10^{3}-10^{5}\end{array}$ & $\begin{array}{l}\text { Insensitive/ } \\
\text { Sensitive }\end{array}$ & {$[44]$} \\
\hline Cymat $^{\mathrm{TM}}$ & $\begin{array}{c}\text { Gas } \\
\text { injection }\end{array}$ & $\begin{array}{c}\mathrm{Al} \\
\mathrm{SiC}\end{array}$ & $0.09(8)$ & $\mathrm{SHPB}^{2}, \mathrm{DHPB}^{3}$ & Insensitive & {$[58]$} \\
\hline Cymat $^{\mathrm{TM}}$ & $\begin{array}{c}\text { Gas } \\
\text { injection }\end{array}$ & $\begin{array}{c}\mathrm{Al} \\
\mathrm{SiC}\end{array}$ & $0.10-0.24(3.37-4.37)$ & Drop weight, $10^{-3}-10^{2}$ & Insensitive & {$[59]$} \\
\hline
\end{tabular}

${ }^{*}$ Osenter Metal Composite Materials Co. Ltd., Shanghai, China; ${ }^{1} \rho$ and $\rho_{\mathrm{s}}$ corresponded to the density of foams and solids, respectively; ${ }^{2}$ split Hopkinson pressure bar (SHPB); ${ }^{3}$ direct-impact Hopkinson pressure bar (DHPB); ${ }^{4}$ direct tension-compression Hopkinson bar (DTCHB).

specified by the experimental investigations [44] and numerical calculations [46]. These deformation modes were further experimentally confirmed and illustrated by images $[54,60]$. However, the above approach cannot entirely explain the lack of strong strain rate dependence observed in some $\mathrm{Al}$ foams, listed in Table 1. Thus, despite continuous efforts, the problem related to strain rate sensitivity of $\mathrm{Al}$ foams remains open to question, and thus, accumulation of more experimental results is desirable as it was pointed out in [46]. Of importance is that the closed-cell Al foams which demonstrated independence of strain rate the same as opencell $\mathrm{Al}$ foam $[39,57]$ were processed either with matrix $\mathrm{Al}-\mathrm{Si}$ alloys comprising brittle silicon eutectic domains or with adding great amount of brittle $\mathrm{SiC}$ particles being typically used in the gas injection method, as evidenced from Table 1.
Therefore, besides the others factors, differences in micromechanisms of deformation associated with mechanisms of cell collapse, which are associated with the microstructure of the matrix alloy and, hence, cell wall ductility, and toughness, is thought to be helpful to resolve this problem. As to the matter at this issue, investigation of strain rate sensitivity of $\mathrm{Al}$ foams based on alloys of different compositions and performed with the alternative foaming agent such as $\mathrm{CaCO}_{3}$ could be useful. Unfortunately, no evidence concerning dynamic response and localized deformation by indentation of these kinds of $\mathrm{Al}$ foams was previously published.

The effort of the present study is to illuminate the effect of cell wall ductility and toughness on the compressive behaviour of closed-cell $\mathrm{Al}$ foams under static and dynamic 
loading. For the purpose above, two kinds of closed-cell foams based on $\mathrm{Al}$ alloys having different relevant properties were fabricated by the melt process with $\mathrm{CaCO}_{3}$ as the foaming agent and no admixture of $\mathrm{Ca}$ to prevent contamination of the cell wall material by undesirable side products. Attention is primary paid to the stress-strain response including rate hardening and strain rate sensitivity of these $\mathrm{Al}$ foams subjected to quasi-static and dynamic loading as well as to localised deformation by indentation.

\section{Materials and Methods}

2.1. Materials. Two kinds of closed-cell Al foams denoted here as F1 and F2 of compositions listed in Table 2 were used in the experiments. Foam F1 was processed with relatively ductile AlSiMg alloy (similar to 6061 alloy), whereas the high-strength AlZnMg alloy (similar to 7075 alloy) comprising great amount of brittle redundant phases was employed to produce foam F2. The density of the matrix alloys of F1 and F2 foams was $2.7 \mathrm{~g} / \mathrm{cm}^{3}$ and $2.8 \mathrm{~g} / \mathrm{cm}^{3}$, respectively.

Both kinds of $\mathrm{Al}$ foams were fabricated via modified melt processing similar to the Alporas route in which calcium carbonate $\left(\mathrm{CaCO}_{3}\right)$ without $\mathrm{Ca}$ additive was used to prevent contamination of the cell wall material by additional and undesirable side products [32]. According to the developed process, thickening the melt was ensured by prolongation of Al-melt stirring up to $30 \mathrm{~min}$ under ambient atmosphere. Temperature/time history of the foaming process was employed taking into consideration the melting points of matrix alloys [31]. Foamed blocks of $90 \mathrm{~mm}$ in diameter and $180 \mathrm{~mm}$ in height were fabricated using laboratory facility, and then samples for structural characterization and mechanical tests were cut by using the electrodischarge machine.

In addition, samples of solid alloys compositionally corresponding to those of the cell wall materials for studied Al foams were fabricated by casting the stirred melt. Not less than three samples of the solid alloys were machined to use them for the conventional compression tests. Approximated values of yield strength, $\sigma_{\mathrm{s}}$, of solids are listed in Table 2 .

2.2. Structural Characterization. Both Al foams were characterized by relative density $\rho / \rho_{\mathrm{s}}$ (where $\rho$ and $\rho_{\mathrm{s}}$ correspond to the density of foam and solids, respectively), cell morphology (cell shape and size), and cell wall microstructure. Relative density, $\rho / \rho_{\mathrm{s}}$, of $\mathrm{Al}$ foam samples was measured by weighing a sample of known volume and listed in Table 2. Image analyzer equipped by software (SEO-SCAN Color, Sumy, Ukraine) was used to investigate the morphology of the cells. Mean cell size was determined by the data averaging over the surface area of SEM images about $250 \mathrm{~mm}^{2}$. Microstructure examination of $\mathrm{Al}$ foams and solid materials used as matrix alloys was done using scanning electron microscopy (SEM) in both secondary and backscattered modes. Material elementary composition was studied using energy dispersive X-ray spectroscopy (EDS) and electron probe microanalysis (EPMA).
2.3. Mechanical Testing. Two types of specimens were machined from the blocks of $\mathrm{Al}$ foams. Small prismatic specimens with dimensions $20 \times 20 \times 30 \mathrm{~mm}^{3}$ were used to investigate mechanical behaviour of $\mathrm{Al}$ foams under quasistatic compression according to ISO 13314 : 2011. In line with this, dimensions of the specimens in the each of three directions were ten times more than the cell size to avoid the size effect. From three to five specimens of each kind of foam were generally tested to verify reproducibility of the results prior to the choice of typical stress-strain curves for presentation. Following the standardized procedure related to compressive tests, foam samples were inserted between two rigid parallel platens lubricated with antifriction spray, as shown in Figure 1(a). Compression tests were performed using the servo hydraulic testing machine of $20 \mathrm{kN}$ under displacement control with a crosshead speed of $1.42 \mathrm{~mm} / \mathrm{min}$ and $18 \mathrm{~mm} /$ min corresponded to the strain rate of $0.79 \times 10^{-3} \mathrm{~s}^{-1}$ and $1 \times 10^{-2}$, respectively. In addition, strain distribution in $\mathrm{Al}$ foam samples under compression at the strain rate of $1 \times 10^{-2} \mathrm{~s}^{-1}$ was monitored with the CCD camera.

In the experiments related to strain rate dependence, not less than three foamed samples were subjected to uniaxial compression by using the Instron 8802 testing machine (UK) under displacement control with a crosshead speed of $0.18 \mathrm{~mm} / \mathrm{min}, 1.8 \mathrm{~mm} / \mathrm{min}, 18 \mathrm{~mm} / \mathrm{min}$, and $180 \mathrm{~mm} / \mathrm{min}$ to provide strain rates ranging from $10^{-4} \mathrm{~s}^{-1}$ to $10^{-1} \mathrm{~s}^{-1}$.

Cylindrical foamed blocks of $90 \mathrm{~mm}$ in diameter and $60 \mathrm{~mm}$ in height were used in axisymmetric indentation tests to investigate mechanical behaviour of foams under localised loading. Steel spherical-end punch of $32 \mathrm{~mm}$ in diameter was fixed to the crosshead of the Instron 8802 testing machine (UK) to the cover indentation area of $\sim 20$ cells and, hence, represent average response of the foam, as shown in Figure 1(b). The indenter was lubricated by the PTFE spray to minimize the effect of friction. Again, not less than three foamed blocks were tested under a displacement speed of $0.015 \mathrm{~mm} / \mathrm{s}$ corresponding to a strain rate of $10^{-3} \mathrm{~s}^{-1}$.

Finally, in line with the standardized recommendations, a set of mechanical parameters was determined by using stress-strain curves for $\mathrm{Al}$ foams. Attention was paid to determination of plateau stress, $\sigma_{\mathrm{pl}}$, energy absorption, $W$, and energy absorption efficiency, $W_{\text {ef }}$.

Following the term introduced by ISO 13314:2011 for plateau stress, $\sigma_{\mathrm{pl}}$, it was determined as the arithmetical mean of the stresses at $0.1 \%$ strain intervals between $20 \%$ and $30 \%$ compressive strain, while the strain at the densification $\varepsilon_{\mathrm{d}}$ was defined as 1.3 times the plateau stress, $\sigma_{\mathrm{pl}}$, i.e., $\sigma=1.3 \times \sigma_{\mathrm{pl}}$. Energy absorption, $W$, was calculated as the area under the stress-strain curve up to the end of plateau regime $W_{\mathrm{pl}}$, at the densification strain, $\varepsilon_{\mathrm{d}}$, while that up to $50 \%$ strain, $W_{50}$, was also calculated. Energy absorption efficiency, $W_{\text {ef }}$, both at the end of the plateau regime, $W_{\text {efpl }}$, and at the $50 \%$ strain, $W_{\text {ef50, was calculated in line with }}$ standardized recommendations as follows:

$$
W_{\text {ef }}=\frac{W}{\varepsilon_{0} \times \sigma_{\max }} \times 10^{4},
$$

where $W$ is the energy absorption per unit volume $\left(\mathrm{MJ} / \mathrm{m}^{3}\right)$, $W_{\text {ef }}$ is the energy absorption efficiency (\%), $\varepsilon_{0}$ is the upper 
TABLE 2: Characteristics for $\mathrm{Al}$ foams and solids.

\begin{tabular}{lccc}
\hline Foam code & Matrix alloy $($ wt. $\%)$ & Relative density $\left(\rho / \rho_{\mathrm{s}}\right)^{1}$ & Solid yield strength, $\sigma_{\text {ys }}(\mathrm{MPa})$ \\
\hline F1 & Al-1Mg-0.6Si-0.28Cu-0.2Cr & $0.16-0.35$ & $185 \pm 5$ \\
F2 & Al-6.0Zn-2.3Mg-1.7Cu-0.11Mn-0.18Cr & $0.18-0.41$ & $252 \pm 4$ \\
\hline
\end{tabular}

${ }^{1} \rho$ and $\rho_{\mathrm{s}}$ correspond to the density of foams and solids, respectively.

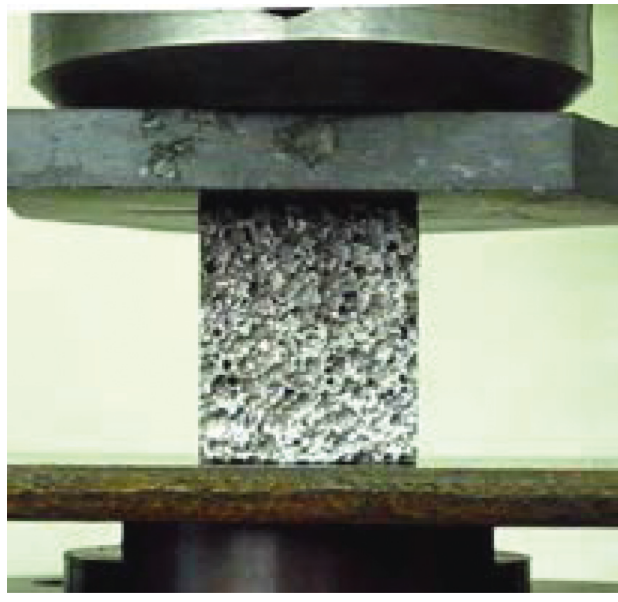

(a)

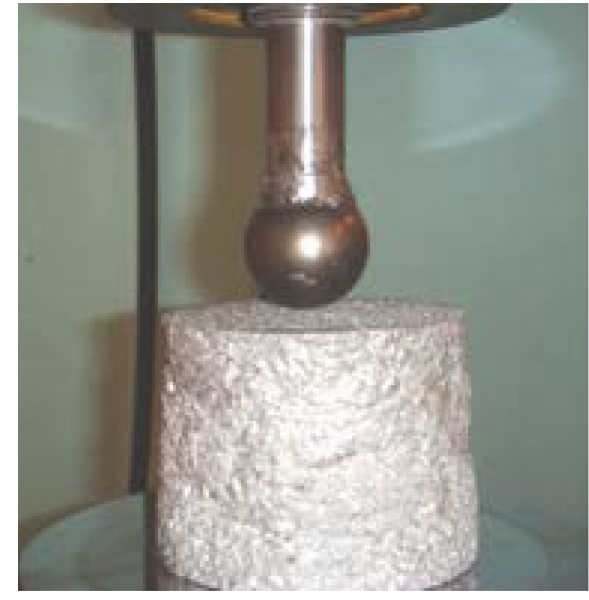

(b)

Figure 1: General view of the samples used in (a) compression and (b) indentation tests.

limit of the compressive strain of interest (\%), and $\sigma_{\max }$ is the compressive stress within the strain range and the magnitude of the strain range of interest $\left(\mathrm{N} / \mathrm{mm}^{2}\right)$.

Dynamic response of the $\mathrm{Al}$ foams was studied in course of direct impact tests using high-pressure air gun. Schematic presentation of arrangement for the impact test is shown in Figure 2.

In the developed arrangement of the direct impact test, flat tipped projectile (1) in form of a hollow cup of $85 \mathrm{~mm}$ in diameter and the mass roughly about $0.5 \mathrm{~kg}$ was fired through the gun barrel (2) onto the surface of the $\mathrm{Al}$ foam specimen (3) mounted on the distal aluminium backing plate (4). Signal associated with the impact pressure was recorded by a pressure gauge (5) fixed between two rigid platens (6) onto the distal plate and transmitted to a computer. This is in contrast to the currently accepted direct impact test, which provides for the fire of the foam specimen forced by a mass within the gun barrel onto the distal flat end equipped by the control system $[39,44]$.

In the present study, specimens of $85 \mathrm{~mm}$ in diameter and $15 \mathrm{~mm}$ were subjected to impact under intermediate velocities ranging from 25 to $60 \mathrm{~m} / \mathrm{s}$ although the developed technique was generally capable to give a striking velocity up to $450 \mathrm{~m} \cdot \mathrm{s}^{-1}$, resulting in sufficiently high kinetic energy. Striking velocity, $V_{\mathrm{o}}$, is provided by adjusting the pressure of air gun and recorded by the in-cycle measuring sensor. Not less than three specimens of the each kind of foam were subjected to impact under given striking velocity, $V_{\mathrm{o}}$.

Postimpact deformation, $\varepsilon$, of $\mathrm{Al}$ foam was determined by simply measuring the specimen height before and after impact, while averaged compressive pressure $P$ associated with compressive stress $\sigma$ at the given strain, $\varepsilon$, was detected

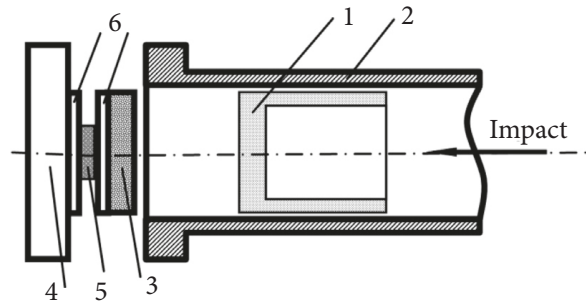

FIGURE 2: Schematic presentation of arrangement for the impact test. (1) Projectile; (2) air gun barrel; (3) Al foam specimen; (4) backing plate; (5) pressure gauge; (6) two rigid platens.

by the pressure gauge. Other relevant impact characteristics were calculated on the basis of fundamental law of energy conservation and principle of pulse balance. In particular, energy absorption per unit volume, $W$, was calculated in line with the commonly accepted procedure by integration of the load-displacing relation as follows:

$$
W=\int_{0}^{\varepsilon} P(\varepsilon) d \varepsilon=\int_{0}^{\varepsilon} \sigma(\varepsilon) d \varepsilon .
$$

Elapsed time after impact, $t$, was estimated taking into consideration striking velocity, $V_{\mathrm{o}}$, and residual velocity, $V_{\mathrm{r}}$, defined as that just at the impact of the $\mathrm{Al}$ foam sample attached to the distal plate. Detailed description of the test method procedure and relationships can be found in [67].

\section{Results and Discussion}

3.1. Material Characterization. Both kinds of $\mathrm{Al}$ foams demonstrate rather a uniform cellular structure over foamed 
blocks and have closed cells of almost spherical shape [30]. Cells of mean size of $1.5 \mathrm{~mm}$ (standard deviation $\pm 0.5 \mathrm{~mm}$ ) are found to be typical for both kinds of $\mathrm{Al}$ foams. As it is shown in Figure 3, the microstructure of the cell wall materials for studied Al foams F1 and F2 is rather similar to that indicative of the matrix alloys.

In particular, thin eutectic domains compositionally corresponding to either $\mathrm{E}\left\{\alpha-\mathrm{Al}+\mathrm{S}\left(\mathrm{Al}_{2} \mathrm{CuMg}\right)\right.$-phase $\}$ (light grey) or $\mathrm{E}\left(\alpha-\mathrm{Al}+\mathrm{Mg}_{2} \mathrm{Si}\right)$ (black) are revealed in both matrix AlSiMg alloy and the cell wall material of F1 foam, as can be seen in Figures 3(a) and 3(c). As it is shown in Figures 3(b) and 3(c), the interdendritic network of course eutectic domains compositionally corresponding to brittle redundant phases such as the mixture of $\mathrm{T}\left(\mathrm{Al}_{2} \mathrm{Mg}_{3} \mathrm{Zn}_{3}\right)$ (dark grey) and isomorphic $\mathrm{T}\left(\mathrm{Al}_{6} \mathrm{CuMg}_{4}\right)$ (light grey) as well as $\mathrm{M}(\mathrm{AlCuMgZn})$ and $\mathrm{S}\left(\mathrm{CuMgAl}_{2}\right)$ (both white) are revealed in the microstructure of matrix AlZnMg-alloy the same as those visible in the cell wall material of Al foam F2. It is noticeable that significant segregation is typical both for cast matrix alloys and for as-received $\mathrm{Al}$ foams.

\subsection{Compressive Response of Al Foams. Figure 4 shows} stress-strain curves for F1 and F2 foams of comparable relative density $\rho / \rho_{\mathrm{s}} \sim 0.28$, both performed under a strain rate of $10^{-2} \mathrm{~s}^{-1}$.

It can be seen that the above $\mathrm{Al}$ foams demonstrate deformation patterns rather similar to those observed for closed-cell Al foams under quasi-static compression $[1,5,21,22]$. Significant difference in compressive behaviour of $\mathrm{Al}$ foams is revealed within the plateau regime. In particular, Al foam F1 deforms almost smoothly and demonstrates only a few number of minor hardening/softening sequences superimposed upon an increasing plateau stress level that is typical for plastic buckling $[22,35]$. As opposed to this $\mathrm{Al}$ foam, F2 demonstrates strong oscillations of plateau stress, which is usually associated with brittle failure of the cell walls $[21,27,37]$. In fact, high fraction volume of coarse and brittle redundant phases impairs cell wall ductility and toughness of Al foam F2. Brittle fracture of the cell walls by cracking lengthways brittle eutectic domains of redundant phases was clearly shown in SEM images of the AlZnMg foam $[3,27]$. Thus, it can be resumed that compressive behaviour of $\mathrm{Al}$ foam $\mathrm{F} 1$ is mainly controlled by plastic buckling of the cell walls, whereas the brittle failure mode contributes significantly in the mechanical response of $\mathrm{Al}$ foam F2. Because of this hardening rate for Al foam F1 is faster than that for Al foam F2, as can be seen in Figure 4. In relatively ductile $\mathrm{Al}$ foam $\mathrm{F} 1$, tensile membrane stress being originated under the pressure of entrapped gas leads to stretching of cell faces and, as consequence, causes the plateau stress to rise up [1]. In $\mathrm{Al}$ foam F2, the above effect is much weaker since brittle failure of the cell walls favours cell connection and, as a consequence, decrease of entrapped gas pressure and, thus, hardening rate. As a result, extension of the plateau regime of $\mathrm{Al}$ foam $\mathrm{F} 2$ becomes much longer than that of $\mathrm{Al}$ foam $\mathrm{F} 1$ although both kinds of $\mathrm{Al}$ foams commence to densify at the same stress, as can be seen in Figure 4(a). Therefore, capability to absorb energy of $\mathrm{Al}$ foam F2 is much higher compared to that of Al foam F1. The validity of this argumentation can be justified experimentally by comparison of energy absorption, $W_{\mathrm{pl}}$, for two kinds of $\mathrm{Al}$ foams (F1 and F2). The results of the test show that energy absorption, $W_{\mathrm{pl}}$, at the end of the plateau regime, $\varepsilon_{\mathrm{d}}$, of $\mathrm{Al}$ foam $\mathrm{F} 2$ superiors to that for $\mathrm{Al}$ foam $\mathrm{F} 1$, as evidenced from Figure 4(b) and Table 3.

Energy absorption, $W$, for both kinds of $\mathrm{Al}$ foams becomes very close when compressive strain, $\mathcal{E}$, reaches $50 \%$ although its efficiency, $W_{\text {ef }}$, was found to be different. Energy absorption efficiency, $W_{\text {ef }}$, was determined when compressive strain reaches either $50 \%$ or the strain value at the plateau end, $\varepsilon_{\mathrm{d}}$. The results show that energy absorption efficiency, $W_{\text {efpl }}$, at the end of the plateau regime of Al foam $\mathrm{F} 2$ was believed to be roughly about $75 \%$ while that of $\mathrm{Al}$ foam $\mathrm{F} 1$ is smaller almost by $12 \%$. Again, parameter $W_{\text {ef50 }}$ calculated at the compressive strain of $50 \%$ of Al foam F2 is roughly about $85 \%$ while that of $\mathrm{Al}$ foam $\mathrm{F} 1$ is found to be only $54 \%$. This could be explained by the fact that, at the compressive strain of $50 \%$, Al foam F1 deforms within the densification regime, while $\mathrm{Al}$ foam F2 densifies by cell collapse typical for the plateau regime.

Figure 5 shows specific events for compressive behaviour of studied $\mathrm{Al}$ foams, which were detected by monitoring the samples with CCD camera in the quasi-static regime.

It can be seen that nonuniform deformation is symptomatic for both kinds of $\mathrm{Al}$ foams (F1 and F2) although it is more evident for $\mathrm{Al}$ foam $\mathrm{F} 2$. When $\mathrm{Al}$ foams are subjected to compression, strain tends to be localized within a narrow crush band and generates buckling of cell walls and stretching of cell faces [22], remaining intact adjacent regions of the cells. With increasing nominal strain, the number of crush bands increases. When $\mathrm{Al}$ foams are subjected to compression, strain tends to be localized within a narrow crush band and favours either buckling of cell walls or brittle fracture of the cells [21, 22, 37], remaining intact adjacent regions of the cells. As deformation progresses, the number of crush bands increases. Crushing originally initiated in a single band proceeds by jump from one layer to the other, covering subjacent areas of material. In addition, localized crush shear bands are formed at a particular nominal strain, resulting in oscillations of plateau stress. Crushing of the cells for both kinds of Al foams (F1 and F2) is accompanied by side sliding that intensifies as nominal strain increases. A noticeable difference is that the lateral spreading of the yield surface of $\mathrm{Al}$ foam $\mathrm{F} 1$ is much smaller than that of $\mathrm{Al}$ foam F2. In addition, cooperative collapse results in formation of an inclined crush "shear" and approximately horizontal zone of localised deformation when compressive strain exceeds the value of $\varepsilon \geq 0.3$. When straining Al foam F2, some cell wall fragments are ejected from sample boundary, indicative of local brittle fracture.

It is useful to process stress-strain curves for above kinds of $\mathrm{Al}$ foams (F1 and F2) taking into consideration the true stress determined in line with Deshpande and Fleck approach [68]. Figure 4(a) shows additional curves presented by true stress vs. nominal strain being determined with regard to this approach. With this purpose true stress was constructed with consideration for actual cross section 


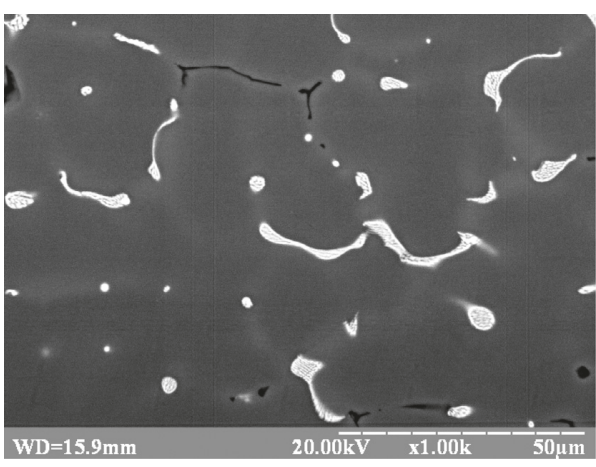

(a)

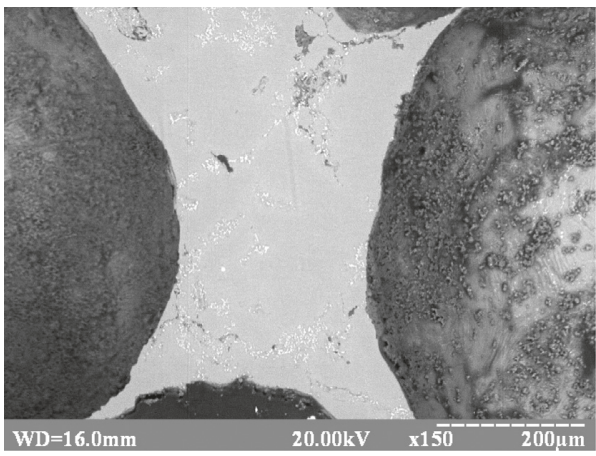

(c)

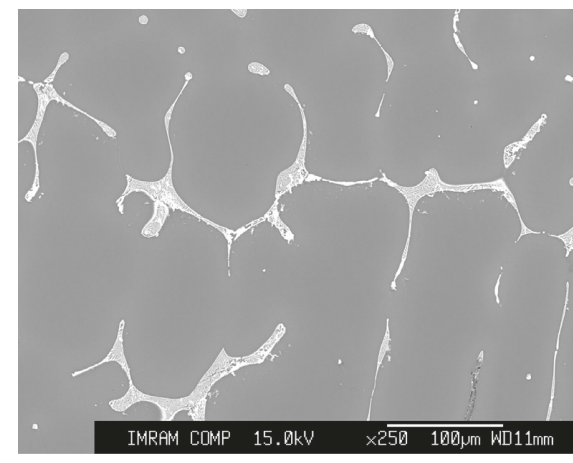

(b)

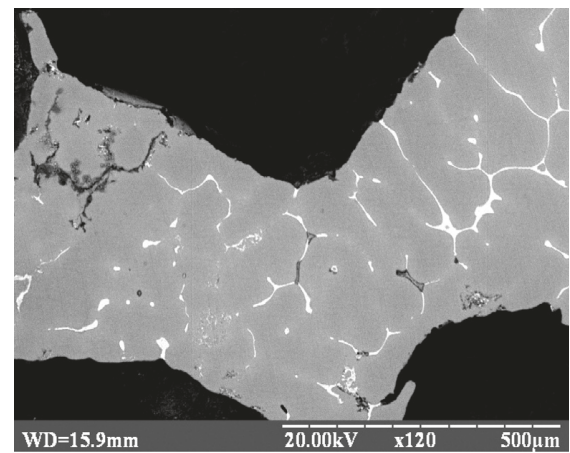

(d)

FIGURe 3: (a, b) SEM micrographs of matrix alloys AlSiMg and AlZnMg, respectively; (c, d) cell wall materials of F1 and F2 foams.

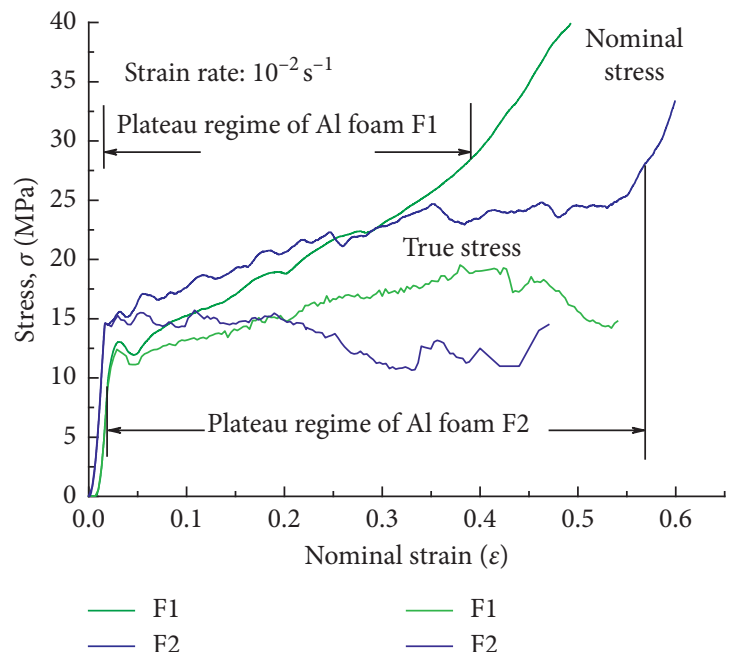

(a)

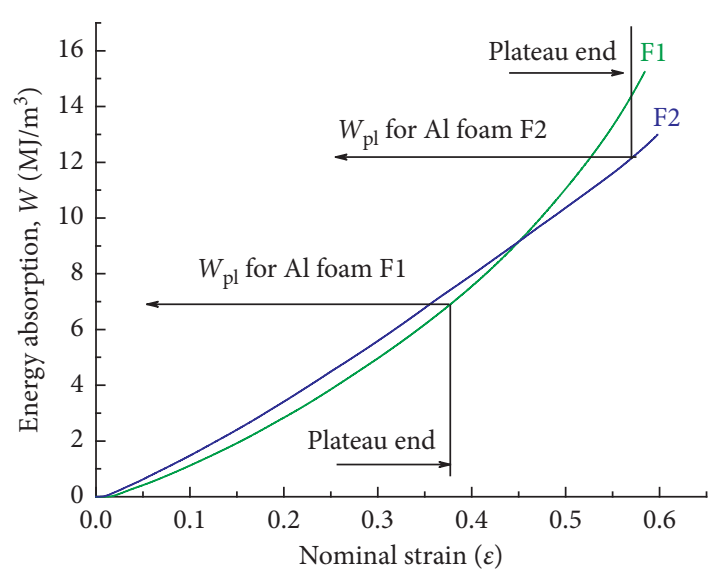

(b)

FIGURE 4: (a) Compressive stress-strain curves and (b) energy absorption vs. nominal strain for two kinds of Al foams (F1 and F2) of comparable relative density $\rho / \rho_{\mathrm{s}} \approx 0.28$.

TABLE 3: Summary of mechanical parameters for $\mathrm{Al}$ foams under compression.

\begin{tabular}{lccccccc}
\hline Foam code & $\sigma_{\mathrm{pl}}(\mathrm{MPa})$ & $\sigma_{\mathrm{d}}(\mathrm{MPa})$ & $\varepsilon_{\mathrm{d}}(\%)$ & $W_{\mathrm{pl}}\left(\mathrm{MJ} / \mathrm{m}^{3}\right)$ & $W_{50 \%}\left(\mathrm{MJ} / \mathrm{m}^{3}\right)$ & $W_{\text {efpl }}(\%)$ & $W_{\text {ef50 }}(\%)$ \\
\hline F1 & 21.27 & 27.66 & 38 & 7.00 & 11.05 & 66.60 & 54.17 \\
F2 & 21.74 & 28.26 & 57 & 12.15 & 10.40 & 75.43 & 84.90 \\
\hline
\end{tabular}




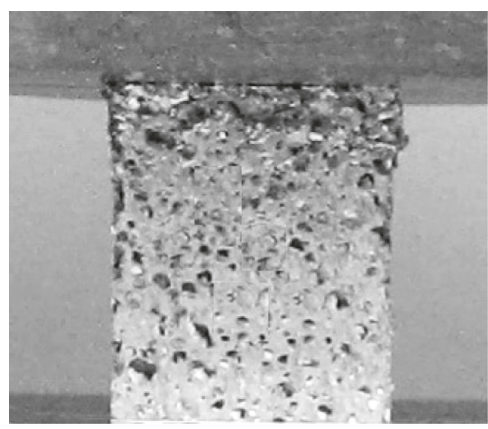

(a)

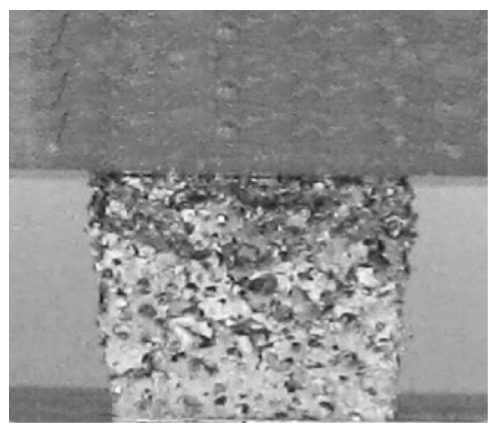

(c)

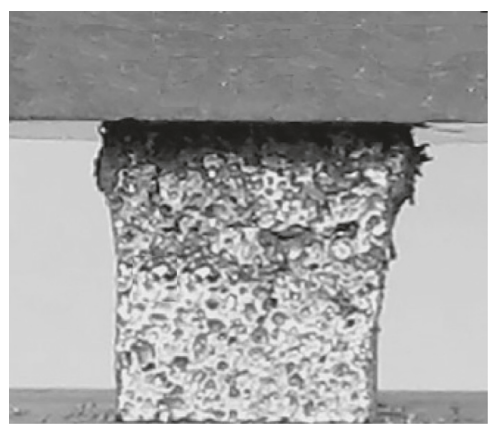

(e)

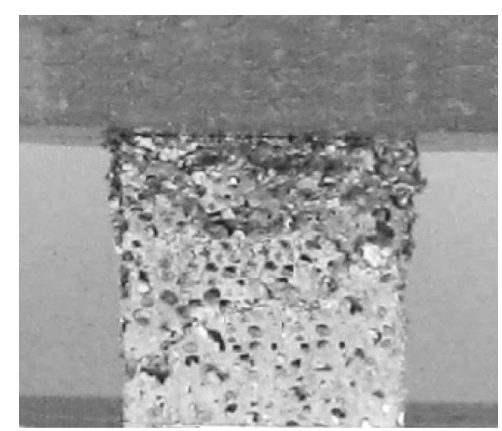

(b)

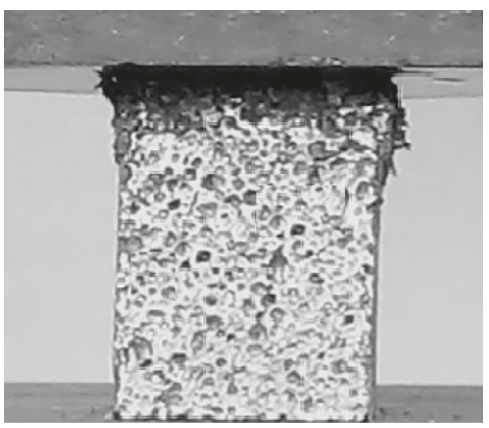

(d)

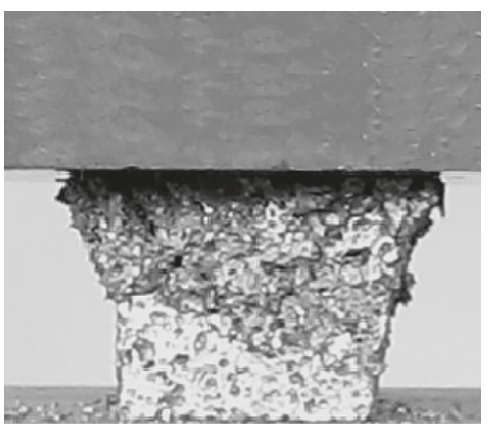

(f)

FIGURE 5: Microphotographs of (a)-(c) Al foam F1 and (d)-(f) Al foam F2, both deformed under the strain rate of $\dot{\varepsilon}=10^{-2} s^{-1}$ to different nominal strains: (a) and (d) $\varepsilon=0.05$; (b) and (e) $\varepsilon=0.2$; (c) and (f) $\varepsilon=0.3$.

resulting from lateral spreading of the yield surface for $\mathrm{Al}$ foams (F1, F2) and recorded by the CCD camera, as shown in Figure 5. Indeed, this approach gives the values of true stress smaller than those of nominal one. Again, essential differences are revealed in compressive behaviour for F1 and F2 foams. True stress of Al foam F1 gradually increases with the increasing nominal strain within the plateau region, as can be seen in Figure 4(a). As opposed to this true stress, for $\mathrm{Al}$ foam, F2 remains at almost a constant level up to the nominal strain of $\varepsilon \approx 0.20$ upon which its value falls down with the increasing strain within the plateau regime and then oscillates almost at the constant level. Thus, the results show that compressive behaviour of $\mathrm{Al}$ foams is strongly dependent on the ductility and toughness of the cell wall material.

Actually, strength degradation of $\mathrm{Al}$ foam $\mathrm{F} 1$ resulted from plastic crushing of relatively ductile cell wall material and takes place at the nominal strain of about $\varepsilon \approx 0.45$. Unlike the above cell wall, fracture of Al foam F2 occurs at smaller by twice nominal strain due to great fraction volume of brittle redundant phases contained by the matrix material, as can be seen in Figure 4(a).

Crucial role of the cell wall ductility and damage behaviour in mechanical performance of the cellular structure in compressive response of F1 and F2 foams becomes especially evident taking into consideration the correlation of plateau strength, $\sigma_{\mathrm{pl}}$, vs. relative density, $\rho / \rho_{\mathrm{s}}$. The latter is usually presented as follows [35]:

$$
\frac{\sigma_{\mathrm{pl}}}{\sigma_{\mathrm{ys}}}=C_{3}\left(\frac{\rho}{\rho_{\mathrm{s}}}\right)^{n}+C_{3}^{\prime}\left(\frac{\rho}{\rho_{\mathrm{s}}}\right),
$$

where $\sigma_{\text {ys }}$ is the solid yield strength, $n=1.5 / 2.0$ is the power index, the constant $C_{3}$ related to cell geometry is roughly about 3 for a wide range of foams, and constant $C_{3}^{\prime}$ related to yielding of stretched cell faces is about 0.44 according to finite element analysis [64] while it possesses zero value for open-cell foams. 
Attention is paid to the difference in the interpretation of the compressive behaviour for $\mathrm{Al}$ foams by application of the theoretical models [35]. The approach used in this present study is the same as in the previous publications [27, 28]. However, plateau stress, $\sigma_{\mathrm{p}}$, was determined between $20 \%$ and 30\% strains as it was recommended by ISO 13314:2011 although yield stress, $\sigma_{\mathrm{y}}$, at the general yielding and plateau stress up to densification, $\sigma_{\mathrm{p} p}$, were employed as input data in $[27,28]$. In addition, approximate values of solid yield strength, which are listed in Table 2, were determined by the conventional compression tests of as-cast matrix alloys in contrast with those performed by conventional tensile tests after a different final heat treatment $[27,28]$.

Figure 6 shows relative compression strength, $\sigma_{\mathrm{pl}} / \sigma_{\mathrm{ys}}$, for two kinds of $\mathrm{Al}$ foams plotted along the lines representing equation (3). It can be seen that a behaviour of two kinds of $\mathrm{Al}$ foams (F1 and F2) deviates from theoretical prediction for closed-cell foams, shifting toward the line prescribed by theory for open-cell foams. This deviation increases as relative density, $\rho / \rho_{s}$, and, hence, cell wall thickness decreases. In any way, the data for plateau stress, $\sigma_{\mathrm{pl}} / \sigma_{\mathrm{ys}}$, of $\mathrm{Al}$ foam $\mathrm{F} 2$ shifts downwards stronger compared to those of $\mathrm{Al}$ foam F1. Thus, the results obtained in the present study confirm once more time that cell collapse in $\mathrm{Al}$ foam $\mathrm{F} 1$ is mainly controlled by cell walls buckling while the brittle failure mode contributes greatly in the cell collapse of $\mathrm{Al}$ foam F2, resulting in crushing deformation bands in brittle manner. Because of this lateral spreading of the yield surface for $\mathrm{Al}$ foam $\mathrm{F} 1$ is quite limited, whereas it is much pronounced for $\mathrm{Al}$ foam F2, as evidenced from Figure 5.

3.3. Quasi-Static Indentation Response of Al Foams. Figure 7 shows indentation response for two kinds of $\mathrm{Al}$ foams (F1 and F2) of comparable relative density, both performed under a strain rate of $10^{-3} \mathrm{~s}^{-1}$.

Indentation stress vs. nominal strain was constructed with regard to the actual contact area until it becomes equal to the diameter of the spherical indenter. Significant difference of indentation response of $\mathrm{Al}$ foam $\mathrm{F} 1$ and that of $\mathrm{Al}$ foam F2 are visible over the entire displacement regime. These differences correlate well with those revealed for mechanical behaviour of F1 and F2 foams under uniaxial compression. In particular, $\mathrm{Al}$ foam $\mathrm{F} 1$ demonstrates almost the smooth stress curve and extremely high hardening rate when continuously increasing the crushed zone of densification underneath the indenter offers resistance for its penetration as it can be seen in Figure 8(a).

As opposed to this, Al foam F2 exhibits high level of stress strongly oscillating within the long deformation plateau regime. Another characteristic feature concerns the deformed zone underneath the indenter. Observation of deformation morphology in the sectioned specimens of $\mathrm{Al}$ foam F2 show tear cracking that extends ahead of the indenter, as it is clearly seen in Figure 8 (b). In addition, densification strain, $\varepsilon_{\mathrm{d}}$, at the end of plateau regime for $\mathrm{Al}$ foam $\mathrm{F} 1$ is limited to roughly about $30 \%$, whereas those for $\mathrm{Al}$ foam F2 is about 50\%, as shown in Figure 7. This is also in good correspondence with the results revealed in quasi-static

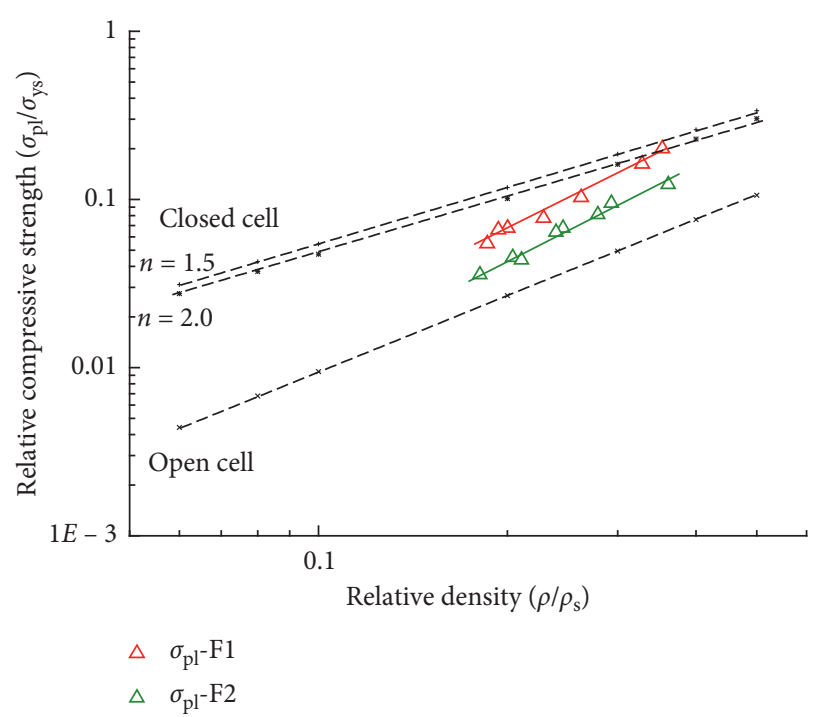

FIgURE 6: Relative compressive strength, $\sigma_{\mathrm{pl}} / \sigma_{\mathrm{ys}}$, plotted against relative density, $\rho / \rho_{\mathrm{s}}$, for two kinds of $\mathrm{Al}$ foams.

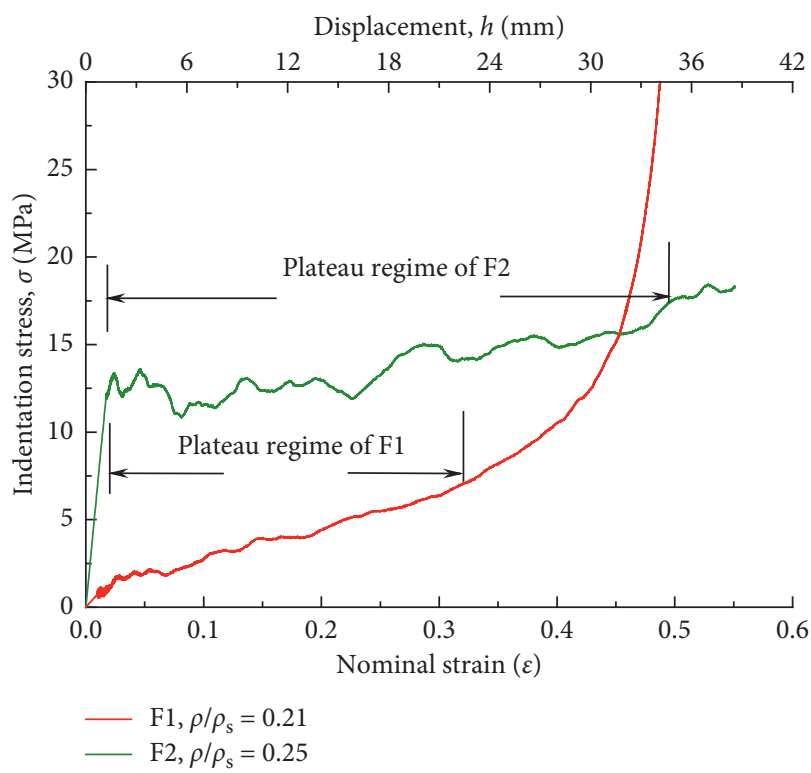

FIGURE 7: Indentation stress vs. nominal strain for two kinds of $\mathrm{Al}$ foams (F1 and F2) of comparable relative density.

tests under compression which are presented in Figure 4. Thus, the results of quasi-static indentation validate also an important effect of localized brittle failure on the mechanism of cells collapse and, hence, on the mechanical response of $\mathrm{Al}$ foam.

3.4. Impact Response and Strain Rate Sensitivity of Al Foams. Mechanical response of two kinds of $\mathrm{Al}$ foams (F1 and F2) compressed under loading with the strain rate ranging from $10^{-4}$ to $10^{-1} \mathrm{~s}^{-1}$ was compared to that recorded under direct impact with strain rate as high as $10^{3} \mathrm{~s}^{-1}$. In particular, the results of direct impact performed at the striking velocity of about $V_{\mathrm{o}}=43 \mathrm{~m} \cdot \mathrm{s}^{-1}$ were employed to estimate strain rate 


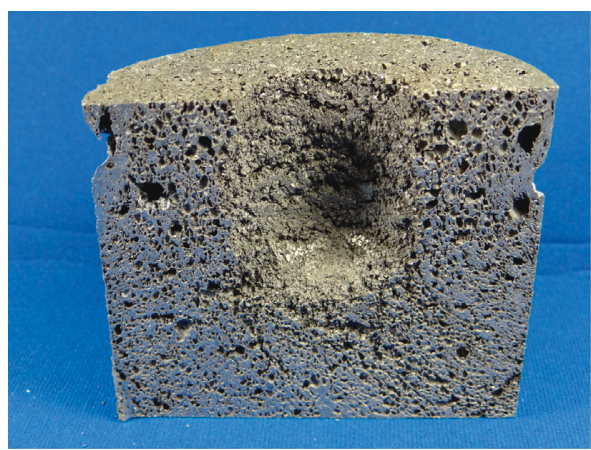

(a)

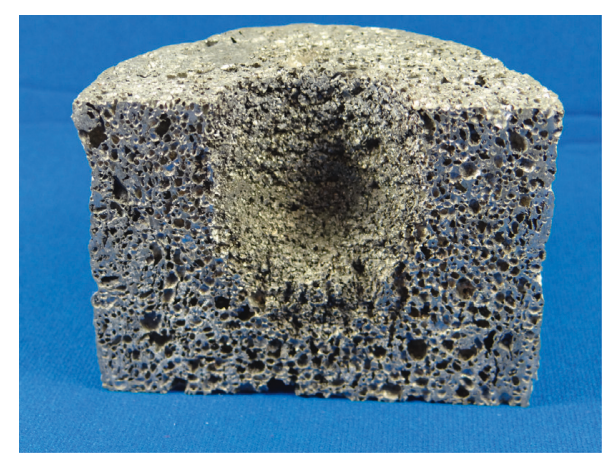

(b)

FIgURE 8: Cross-sectional view of indentations showing the deformed zone underneath the indenter: (a) Al foam F1; (b) Al foam F2.

sensitivity of the studied $\mathrm{Al}$ foams of comparable relative density, $\rho / \rho_{\mathrm{s}}$. Samples of $\mathrm{Al}$ foam $\mathrm{F} 1$ with $\rho / \rho_{\mathrm{s}} \sim 0.26$ and $\mathrm{Al}$ foam F2 with $\rho / \rho_{\mathrm{s}} \sim 0.24$ were subjected to the impact. It is noticeable that postimpact deformation was found to be different for F1 and F2 foams. Specimens of Al foam F1 were deformed to the strain of $\varepsilon=0.17$, while those of Al foam F2 were compressed to the strain of about $\varepsilon=0.30$.

For that reason, values of the strength, $\sigma$, and, hence, energy absorption, $W$, measured at the direct impact were thought to be reasonably compared with those exhibited by $\mathrm{Al}$ foams at the equivalent compressive strains under quasistatic loading. In terms of the above approach, variation of strength, $\sigma$, and energy absorption, $W$, for studied $\mathrm{Al}$ foams with the increasing strain rate from $10^{-4}$ to $10^{3} \mathrm{~s}^{-1}$ is shown in Figure 9.

It can be seen that $\mathrm{Al}$ foam $\mathrm{F} 1$ based on the relatively ductile matrix alloy demonstrates bilinear increase of strength and, hence, energy absorption with the increasing strain rate from $10^{-4}$ to $10^{3} \mathrm{~s}^{-1}$. These parameters increase relatively slowly as the strain rate increases up to $10^{-1} \mathrm{~s}^{-1}$ and then rise steeply at a higher strain rate. These results are in good agreement with those published previously for $\mathrm{Al}$ foams with trade mark "Alporas" [24, 49, 50]. Generally, rate-sensitive response is generally attributed to microinertia effects. According to the theoretical consideration proposed by Klintworth and Stronge [69], microinertia has very little effect at low strain rates when the micromechanism of deformation is dominated by cell wall buckling. Microinertia effect becomes significant at high strain rates since buckling is suppressed by the inertia of the cell walls. This microinertia results in enhancement of the plastic strength and tends to disperse strain localization. Based on the above concept, it can be thought that the microinertial effect is the reason of bilinearity observed for Al foam F1 whose cell walls are relatively ductile for buckling.

In contrast to this, $\mathrm{Al}$ foam $\mathrm{F} 2$ based on high-strength and brittle matrix alloy exhibits slight increasing both in the strength and energy absorption, suggesting negligible strain rate sensitivity, as shown in Figure 9. It is noticeable that the same weak sensitivity to strain rate of closed-cell foams based on high-strength alloys of chemical compositions Al$5 \mathrm{Zn}-1 \mathrm{Mg}$ and $\mathrm{Al}-7 \mathrm{Zn}-0.5 \mathrm{Mg}$, both performed via the Alporas route and processed with $\mathrm{TiH}_{2}$ and $\mathrm{Ca}$ additive, was previously reported in [55-57]. Of importance is that the weak sensitivity of the above foams was found to be caused by brittle fracture of their cell wall material. Attention is paid to the fact that both kinds of studied $\mathrm{Al}$ foams (F1 and F2) display almost the same energy absorption ability at the strain rate as high as $10^{3} \mathrm{~s}^{-1}$ although the strength, $\sigma$, of the $\mathrm{Al}$ foam F1 much superiors to that of $\mathrm{Al}$ foam $\mathrm{F} 2$. In addition, elapsed time, $t$, of $\mathrm{Al}$ foam F2 was found to be much longer than that of $\mathrm{Al}$ foam $\mathrm{F} 1$, i.e., $2.64 \times 10^{-4} \mathrm{~s}$ and $1.57 \times 10^{-4} \mathrm{~s}$, respectively. From the standpoint of damage tolerance, this is an indisputable advantage of $\mathrm{Al}$ foam F2 compared to Al foam F1. Thus, the results of the study show that optimization of ductility and toughness of the cell walls of $\mathrm{Al}$ foams is essentially important for controlling their strain rate sensitivity.

\section{Conclusions}

Significant effect of cell wall ductility on the compressive response of closed-cell $\mathrm{Al}$ foams subjected to static and dynamic loading conditions over the wide range of strain rate from $10^{-4}$ to $10^{3} \mathrm{~s}^{-1}$ was found and experimentally validated.

Compressive behaviour and indentation response of AlSiMg foam was found to be mainly controlled by plastic buckling of the cell walls, whereas contribution of the brittle failure mode in cell collapse and, hence, in macroscopic mechanical response was believed to be inherent for $\mathrm{AlZnMg}$ foam. Characteristic features of compressive response of the studied $\mathrm{Al}$ foams resulting from the different mechanism of cell collapse were pointed out and summarised in the following manner.

In uniaxial compression and indentation tests, AlSiMg foam demonstrates almost smooth deformation patterns while strong oscillation of plateau stress is typical for $\mathrm{AlZnMg}$ foam. In addition, lateral spreading of the yield surface of AlSiMg foam is much smaller than that of $\mathrm{AlZnMg}$ foam as it was recognized by samples monitoring with CCD camera during quasi-static compression. In the indentation tests, the crushed zone of the compacted material underneath the indenter offers resistance for its penetration in AlSiMg foam while tear cracking ahead of the indenter favours easy localized deformation. 


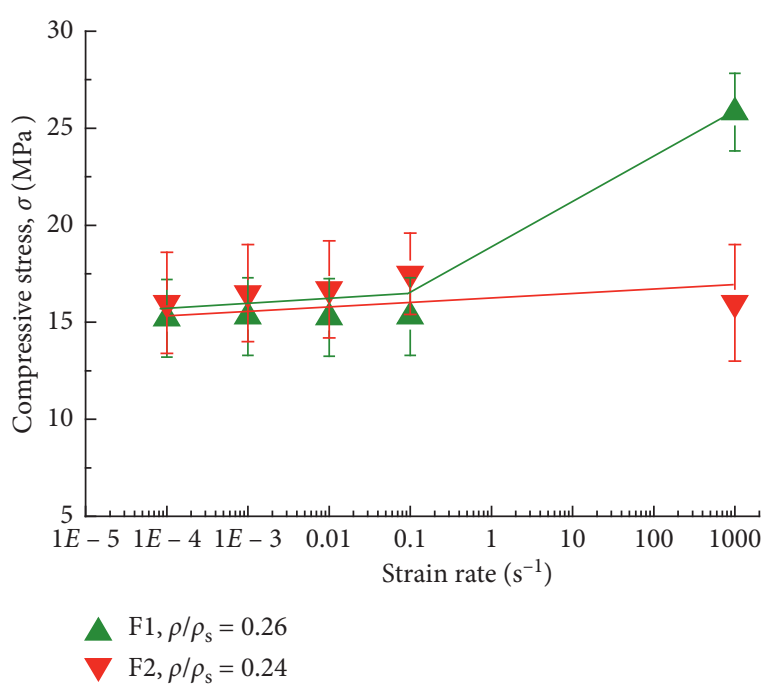

(a)

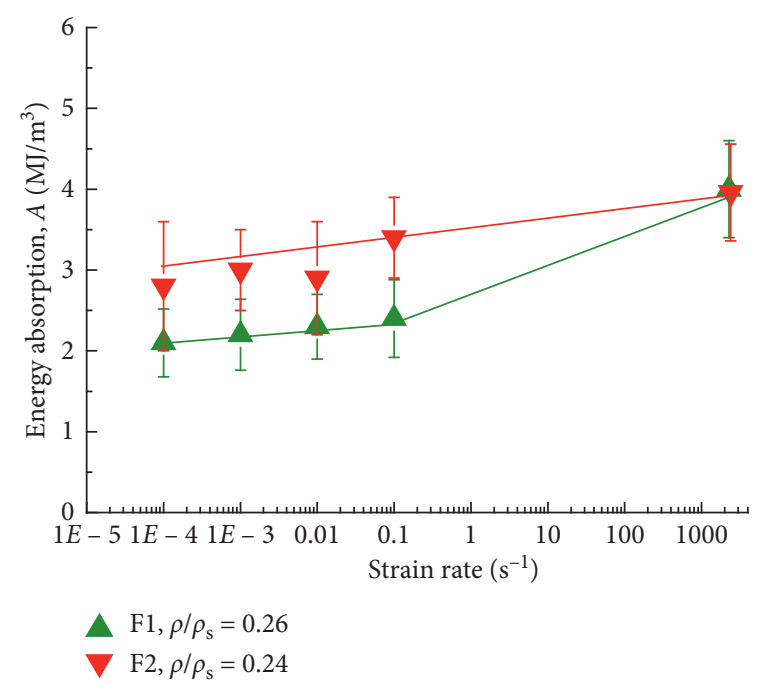

(b)

FIGURE 9: Variation of (a) strength and (b) energy absorption with the increasing strain rate for two kinds of $\mathrm{Al}$ foams (F1 and F2).

Of importance is the fact that contribution of the brittle failure mode in the cell collapse of $\mathrm{AlZnMg}$ foam favours the plateau regime to be much longer compared to that of AlSiMg foam. As a result, $\mathrm{AlZnMg}$ foam discloses grater energy absorption ability than AlSiMg foam.

Negligible strain rate sensitivity was found to be indicative of AlZnMg foam in contrast to strain sensitive response of AlSiMg foam. Variation of dynamic stress, $\sigma$, and energy absorption, $W$, detected for AlSiMg foam follows bilinear functional dependence with transition to steep growth at a nominal strain rate of $10^{-1} \mathrm{~s}^{-1}$ that is typical for rate response controlled by microinertial effects.

The results of this study highlight crucial role of cell wall ductility and toughness in terms of their effect on compressive response and strain rate sensitivity of $\mathrm{Al}$ foams. In addition, these results could be valuable for application in engineering practice and, particularly, in design of crashworthy structures. From the standpoint of efficient dissipation of impact energy and damage tolerance of integral metal/ceramic/glass fibre composites, the use of $\mathrm{AlZnMg}$ foam as the core material is thought to be more preferable compared to AlSiMg foam.

\section{Data Availability}

The data used to support the findings of this study are available from the corresponding author upon request. We state that the dataset(s), code, and other digital research materials supporting the results in the article are available from the corresponding author upon request.

\section{Conflicts of Interest}

The authors declare that they have no conflicts of interest.

\section{Acknowledgments}

Special thanks are due to Professor T. Nakamura of Tohoku University, Japan, for cooperation and fruitful discussions and to other researchers for their help with electron microscopy. This research was supported by the National Academy of Sciences of Ukraine under Project nos. III-7-16 and II-7-18.

\section{References}

[1] F. Ashby, A. G. Evans, N. A. Fleck et al., Metal Foams: A Design Guide, Butterworth Heinemann, Boston, MA, USA, 2000.

[2] J. Banhart, "Manufacture, characterisation and application of cellular metals and metal foams," Progress in Materials Science, vol. 46, no. 6, pp. 559-632, 2001.

[3] A. Byakova, S. Gnyloskurenko, Y. Bezimyanniy, and T. Nakamura, "Closed-cell aluminum foam of improved sound absorption ability: manufacture and properties," Metals, vol. 4, no. 3, pp. 445-454, 2014.

[4] W. Yuan, Y. Li, and X. Chen, "Improving sound absorption of aluminum foams by drilling holes," Chinese Journal of Nonferrous Metals, vol. 21, no. 1, pp. 138-144, 2011.

[5] Z. Xu and H. Hao, "Electromagnetic interference shielding effectiveness of aluminum foams with different porosity," Journal of Alloys and compounds, vol. 617, pp. 207-213, 2014.

[6] X. Zhu, S. Ai, X. Lu, X. Ling, L. Zhu, and B. Liu, "Thermal conductivity of closed-cell aluminum foam based on the 3D geometrical reconstruction," International Journal of Heat and Mass Transfer, vol. 72, pp. 242-249, 2014.

[7] P. Schaeffler, W. Rajner, D. Claar, T. Trendelenburg, and H. Nishimura, "Production, properties, and applications of Alulight ${ }^{\circledR}$ closed-cell aluminum foams," in Proceedings of the Fifth International Workshop on Advanced Manufacturing Technologies, London, Canada, May 2005.

[8] Y. Wang, X. Zhai, and W. Wang, "Numerical studies of aluminum foam filled energy absorption connectors under quasi-static compression loading," Thin-Walled Structures, vol. 116, pp. 225-233, 2017.

[9] V. Crupi, G. Epasto, and E. Guglielmino, "Impact response of aluminum foam sandwiches for light-weight ship structures," Metals, vol. 1, no. 1, pp. 98-112, 2011. 
[10] V. Crupi, G. Epasto, and E. Guglielmino, "Comparison of aluminium sandwiches for lightweight ship structures: honeycomb vs. foam," Marine Structures, vol. 30, pp. 74-96, 2013.

[11] J. Banhart and H.-W. Seeliger, "Aluminium foam sandwich panels: manufacture, metallurgy and applications," Advanced Engineering Materials, vol. 10, no. 9, pp. 793-802, 2008.

[12] M. I. Idris, T. Vodenitcharova, and M. Hoffman, "Mechanical behaviour and energy absorption of closed-cell aluminium foam panels in uniaxial compression," Materials Science and Engineering: A, vol. 517, no. 1-2, pp. 37-45, 2009.

[13] B. A. Gama, T. A. Bogetti, B. K. Fink et al., "Aluminum foam integral armor: a new dimension of armor design," Composite Structures, vol. 52, no. 3-4, pp. 381-395, 2001.

[14] O. Sadot, I. Anteby, S. Harush, and O. Levintant, "Experimental investigation of dynamic properties of aluminum foams," Journal of Structural Engineering, vol. 131, no. 8, pp. 1226-1232, 2005.

[15] E. Markaki and T. W. Clyne, "Characterisation of impact response of metallic foam/ceramic laminates," Materials Science and Technology, vol. 16, no. 7-8, pp. 785-791, 2000.

[16] G. Reyes Villanueva and W. J. Cantwell, "The high velocity impact response of composite and FML-reinforced sandwich structures," Composites Science and Technology, vol. 64, no. 1, pp. 35-54, 2004.

[17] A. Manes, A. Gilioli, C. Sbarufatti, and M. Giglio, "Experimental and numerical investigations of low velocity impact on sandwich panels," Composite Structures, vol. 99, pp. 8-18, 2013.

[18] J. Wang, A. M. Waas, and H. Wang, "Experimental and numerical study on the low-velocity impact behavior of foamcore sandwich panels," Composite Structures, vol. 96, pp. 298-311, 2013.

[19] L. Jing, Z. Wang, V. P. W. Shim, and L. Zhao, "An experimental study of the dynamic response of cylindrical sandwich shells with metallic foam cores subjected to blast loading," International Journal of Impact Engineering, vol. 71, pp. 6072, 2014.

[20] V. Crupi, E. Kara, G. Epasto, E. Guglielmino, and H. Aykul, "Prediction model for the impact response of glass fibre reinforced aluminium foam sandwiches," International Journal of Impact Engineering, vol. 77, pp. 97-107, 2015.

[21] A. E. Markaki and T. W. Clyne, "The effect of cell wall microstructure on the deformation and fracture of aluminiumbased foams," Acta Materialia, vol. 49, no. 9, pp. 1677-1686, 2001.

[22] L. J. Gibson and M. F. Ashby, Cellular Solids: Structure and Properties, Cambridge University Press, Cambridge, UK, 1997.

[23] O. B. Olurin, N. A. Fleck, and M. F. Ashby, "Indentation resistance of an aluminium foam," Scripta Materialia, vol. 43, no. 11, pp. 983-989, 2000.

[24] S. Ramahandra, P. Sudheer Kumar, and U. Ramamurty, "Impact energy absorption in an $\mathrm{Al}$ foam at low velocities," Scripta Materialia, vol. 49, no. 8, pp. 741-745, 2003.

[25] Z. Li, Z. Zheng, J. Yu, and L. Tang, "Effect of temperature on the indentation behavior of closed-cell aluminum foam," Materials Science and Engineering: A, vol. 550, pp. 222-226, 2012.

[26] J. Banhart, "Light-metal foams-history of innovation and technological challenges," Advanced Engineering Materials, vol. 15, no. 3, pp. 82-111, 2013.

[27] A. Byakova, I. Kartuzov, S. Gnyloskurenko, and T. Nakamura, "The role of foaming agent and processing route in mechanical performance of fabricated aluminum foams,"
Advances in Materials Science and Engineering, vol. 2014, Article ID 607429, 9 pages, 2014.

[28] A. Byakova, S. Gnyloskurenko, and T. Nakamura, "The role of foaming agent and processing route in the mechanical performance of fabricated aluminum foams," Metals, vol. 2, no. 2, pp. 95-112, 2012.

[29] T. Nakamura, S. V. Gnyloskurenko, K. Sakamoto, A. N. V. Byakova, and R. Ishikawa, "Development of new foaming agent for metal foam," Materials Transactions, vol. 43, no. 5, pp. 1191-1196, 2002.

[30] A. V. Byakova, S. V. Gnyloskurenko, A. I. Sirko, Y. V. Milman, and T. Nakamura, "The role of foaming agent in structure and mechanical performance of Al based foams," Materials Transactions, vol. 47, no. 9, pp. 2131-2136, 2006.

[31] V. Byakova, A. I. Sirko, K. V. Mykhalenkov, Y. Milman, S. Gnyloskurenko, and T. Nakamura, "Improvements in stabilisation and cellular structure of $\mathrm{Al}$ based foams with novel carbonate foaming agent," High Temperature Materials and Processes, vol. 26, no. 4, pp. 239-246, 2007.

[32] V. Byakova, A. A. Vlasov, S. V. Gnyloskurenko, and I. Kartuzov, "Method for making the blocks of foamed aluminum/aluminum alloys," UA Patent no. 104367, 2014.

[33] S. Sutarno, B. Nugraha, and Kusharjanto, "Optimization of calcium carbonate content on synthesis of aluminum foam and its compressive strength characteristic," AIP Conference Proceedings, vol. 1805, no. 1, 2017.

[34] A. Erryani, F. P. Lestari, D. Annur, and I. Kartika, "Preparation and characterization of coating sodium trisilicate $\left(\mathrm{Na}_{2} \mathrm{O} . \mathrm{nSiO}_{2}\right)$ at calcium carbonate $\left(\mathrm{CaCO}_{3}\right)$ for blowing agent in $\mathrm{Mg}$ alloy foam," AIP Conference Proceedings, vol. 1964, no. $1,2018$.

[35] L. J. Gibson, "Mechanical behavior of metallic foams," Annual Review of Materials Science, vol. 30, no. 1, pp. 191-227, 2000.

[36] A. Bastawros, H. Bart-Smith, and A. G. Evans, "Experimental analysis of deformation mechanisms in a closed-cell aluminum alloy foam," Journal of the Mechanics and Physics of Solids, vol. 48, no. 2, pp. 301-322, 2000.

[37] B. Kriszt, B. Foroughi, K. Faure, and H. P. Degischer, "Behaviour of aluminium foam under uniaxial compression," Materials Science and Technology, vol. 16, no. 7-8, pp. 792796, 2000.

[38] I. Duarte, M. Vesenjak, and L. Krstulović-Opara, "Compressive behaviour of unconstrained and constrained integralskin closed-cell aluminium foam," Composite Structures, vol. 154, pp. 231-238, 2016.

[39] V. S. Deshpande and N. A. Fleck, "High strain rate compressive behaviour of aluminium alloy foams," International Journal of Impact Engineering, vol. 24, no. 3, pp. 277-298, 2000.

[40] K. A. Dannemann and J. Lankford, "High strain rate compression of closed-cell aluminium foams," Materials Science and Engineering: A, vol. 293, no. 1-2, pp. 157-164, 2000.

[41] Irausquín, I. Perez-Castellanos, J. L. Pérez-Castellanos, V. Miranda, and F. Teixeira-Dias, "Evaluation of the effect of the strain rate on the compressive response of a closed-cell aluminium foam using the split Hopkinson pressure bar test," Materials \& Design, vol. 47, pp. 698-705, 2013.

[42] I. Duarte, M. Vesenjak, and L. Krstulović-Opara, "Variation of quasi-static and dynamic compressive properties in single Aluminium-alloy foam block," Procedia Materials Science, vol. 4, pp. 157-162, 2014.

[43] E. Linul, L. Marsavina, J. Kováčik, and T. Sadovski, "Dynamic and quasi-static compression tests of closed-cell aluminium 
alloy foams," in Proceedings of the Romanian Academy, Series A, vol. 18, no. 4, pp. 361-369, 2017.

[44] P. J. Tan, S. R. Reid, J. J. Harrigan, Z. Zou, and S. Li, "Dynamic compressive strength properties of aluminium foams. Part I-experimental data and observations," Journal of the Mechanics and Physics of Solids, vol. 53, no. 10, pp. 2174-2205, 2005.

[45] J. U. Cho, S. J. Hong, S. K. Lee, and C. Cho, "Impact fracture behavior at the material of aluminum foam," Materials Science and Engineering: A, vol. 539, pp. 250-258, 2012.

[46] Y. D. Liu, J. L. Yu, Z. J. Zheng, and J. R. Li, "A numerical study on the rate sensitivity of cellular metals," International Journal of Solids and Structures, vol. 46, no. 22-23, pp. 3988-3998, 2009.

[47] X. Liu, J. Zhang, Q. Fang, H. Wu, and Y. Zhang, "Response of closed-cell aluminum foams under static and impact loading: experimental and mesoscopic numerical analysis," International Journal of Impact Engineering, vol. 110, pp. 382394, 2017.

[48] E. Linul, L. Marsavina, and J. Kováčik, "Collapse mechanisms of metal foam matrix composites under static and dynamic loading conditions," Materials Science and Engineering: A, vol. 690, pp. 214-224, 2017.

[49] A. Paul and U. Ramamurty, "Strain rate sensitivity of a closedcell aluminum foam," Material Science and Engineering: A, vol. 281, no. 1-2, pp. 1-7, 2000.

[50] T. Mukai, H. Kanahashi, T. Miyoshi, M. Mabuchi, T. G. Nieh, and K. Higashi, "Experimental study of energy absorption in a close-celled aluminum foam under dynamic loading," Scripta Materialia, vol. 40, no. 8, pp. 921-927, 1999.

[51] M. Cady, G. T. Gray III, C. Liu et al., Shock Compression of Condensed Matter, American Institute of Physics, College Park, MD, USA, 2001

[52] M. Cady, G. T. Gray III, C. Liu, and T. Mukai, "Compressive properties of a closed-cell aluminum foam as a function of strain rate and temperature," Materials Science and Engineering: $A$, vol. 525, no. 1-2, pp. 1-6, 2009.

[53] T. Hamada and H. Kanahashi, "Dynamic strength in uniaxial compression of closed cell aluminium foam," in Proceedings Porous Metals and Metal Foaming Technology, pp. 533-538, Kyoto, Japan, 2005.

[54] P. Wang, S. Xu, Zh. Li et al., "Experimental investigation on the strain-rate effect and inertia effect of closed-cell aluminum foam subjected to dynamic loading," Materials Science and Engineering: A, vol. 620, pp. 253-261, 2014.

[55] T. Miyoshi, T. Mukai, and K. Higashi, "Energy absorption in closed-cell Al-Zn-Mg-Ca-Ti foam," Materials Transactions, vol. 43, no. 7, pp. 1778-1781, 2002.

[56] T. Miyoshi, T. Mukai, and K. Hogashi, "Energy absorption in closed-cell Al-Zn-Mg-Ca-Ti foam," in Proceedings Porous Metals and Metal Foaming Technology, pp. 1778-1781, Kyoto, Japan, 2005.

[57] T. Mukai, "Energy absobtion of cellular aluminum alloys at high strain rates," in Proceedings Porous Metals and Metal Foaming Technology, pp. 539-542, Kyoto, Japan, 2005.

[58] H. Zhao, I. Elnasri, and S. Abdennadher, "An experimental study on the behaviour under impact loading of metallic cellular materials International," International Journal of Mechanical Sciences, vol. 47, no. 4-5, pp. 757-774, 2005.

[59] R. Montanini, "Measurement of strain rate sensitivity of aluminium foams for energy dissipation," International Journal of Mechanical Sciences, vol. 47, no. 1, pp. 26-42, 2005.
[60] F. Campana, E. Mancini, D. Pilone, and M. Sasso, "Strain rate and density-dependent strength of AlSi7 alloy foams," Materials Science and Engineering: A, vol. 651, pp. 657-667, 2016.

[61] F. Campana, L. Cortese, and D. Pilone, "Property variations in large AlSi7 alloy foam ingots," Materials Science and Engineering: A, vol. 556, pp. 400-407, 2012.

[62] A. Boschetto, F. Campana, and D. Pilone, "Comparison through image analysis between $\mathrm{Al}$ foams produced using two different methods," Journal of Materials Engineering and Performance, vol. 23, no. 2, pp. 572-580, 2014.

[63] J. Kadkhodapour and S. Raeisi, "Micro-macro investigation of deformation and failure in closed-cell aluminum foams," Computational Materials Science, vol. 83, pp. 137-148, 2014.

[64] A. E. Simone and L. J. Gibson, "The effects of cell face curvature and corrugations on the stiffness and strength of metallic foams," Acta Materialia, vol. 46, no. 11, pp. 39293935, 1998.

[65] U. Ramamurty and A. Paul, "Variability in mechanical properties of a metal foam," Acta Materialia, vol. 52, no. 4, pp. 869-876, 2004.

[66] T. Miyoshi, S. Nishi, S. Furuta, T. Hamada, and K. Yoshikawa, "Current activities and new technologies of aluminium foam by melt route," in Proceedings of the Porous Metals and Metal Foaming Technology, pp. 255-258, Kyoto, Japan, 2005.

[67] A. Byakova, G. Stepanov, A. Vlasov, V. Danilyuk, N. Semenov, and O. Berezovskyi, "Characterisation of Impact Response of Aluminium Foam," Strength of Materials, 2019, In press.

[68] V. S. Deshpande and N. A. Fleck, "Isotropic constitutive models for metallic foams," Journal of the Mechanics and Physics of Solids, vol. 48, no. 6-7, pp. 1253-1283, 2000.

[69] J. W. Klintworth and W. J. Stronge, "Elasto-plastic yield limits and deformation lows for transverse by crushed honecombs," International Journal of Mechanical Sciences, vol. 30, no. 3-4, pp. 273-292, 1988. 


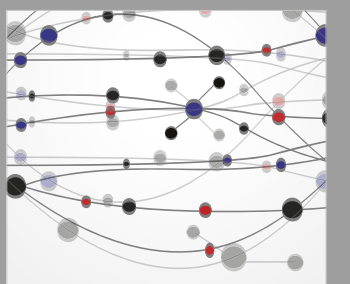

The Scientific World Journal
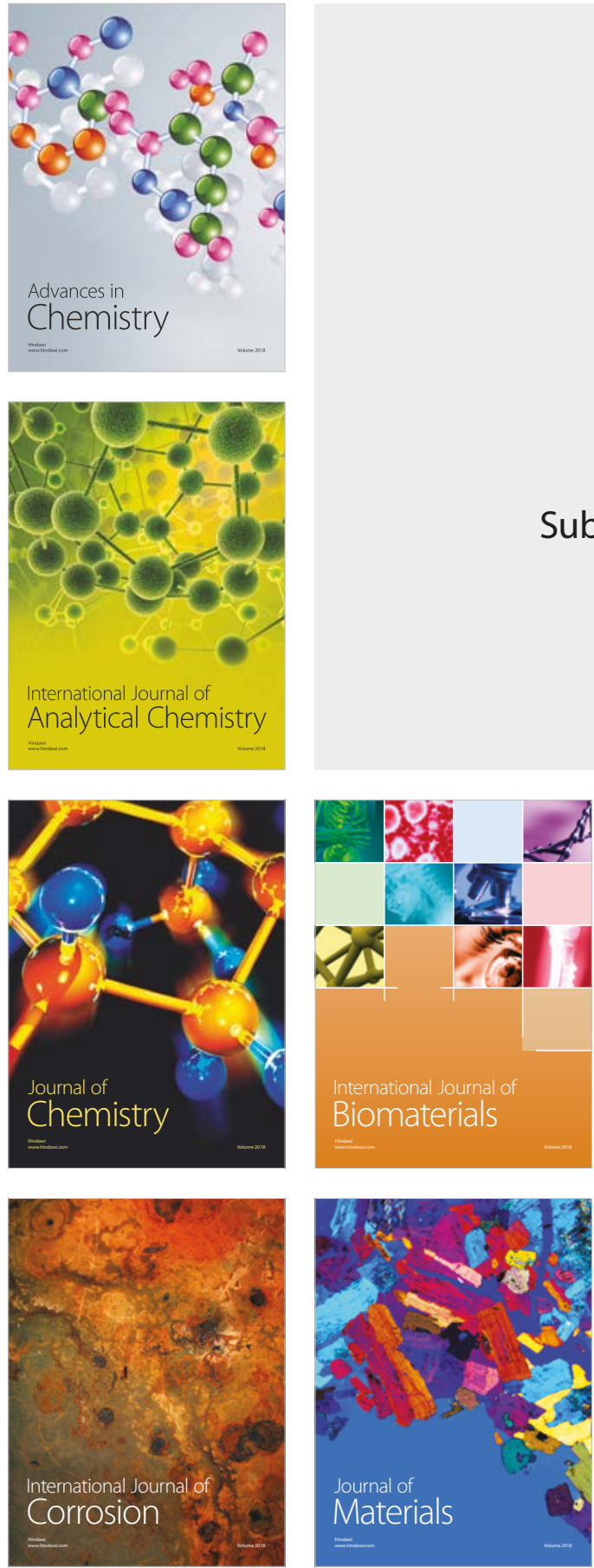

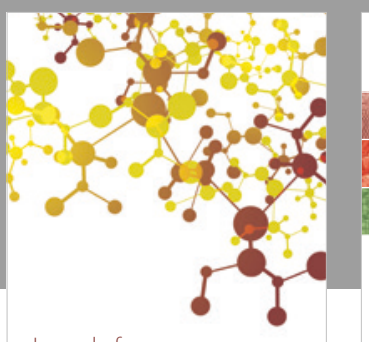

Journal of

Applied Chemistry
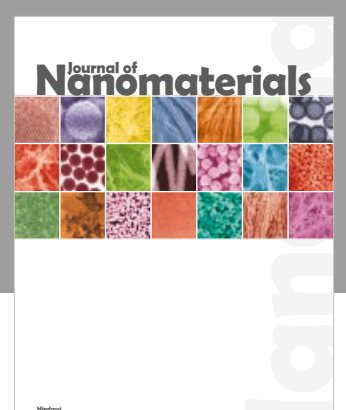

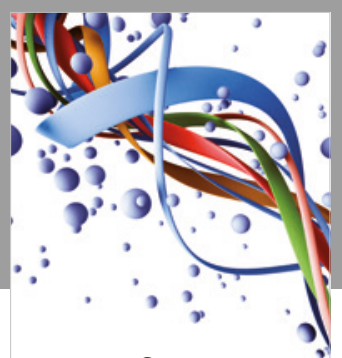

Scientifica

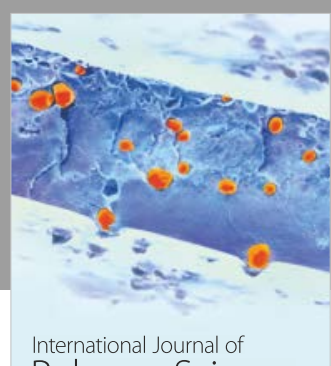

Polymer Science

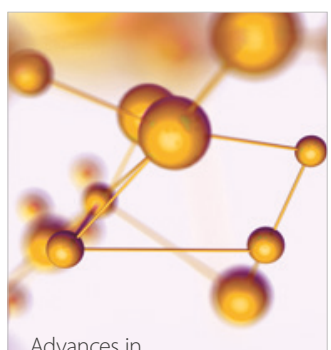

Physical Chemistry
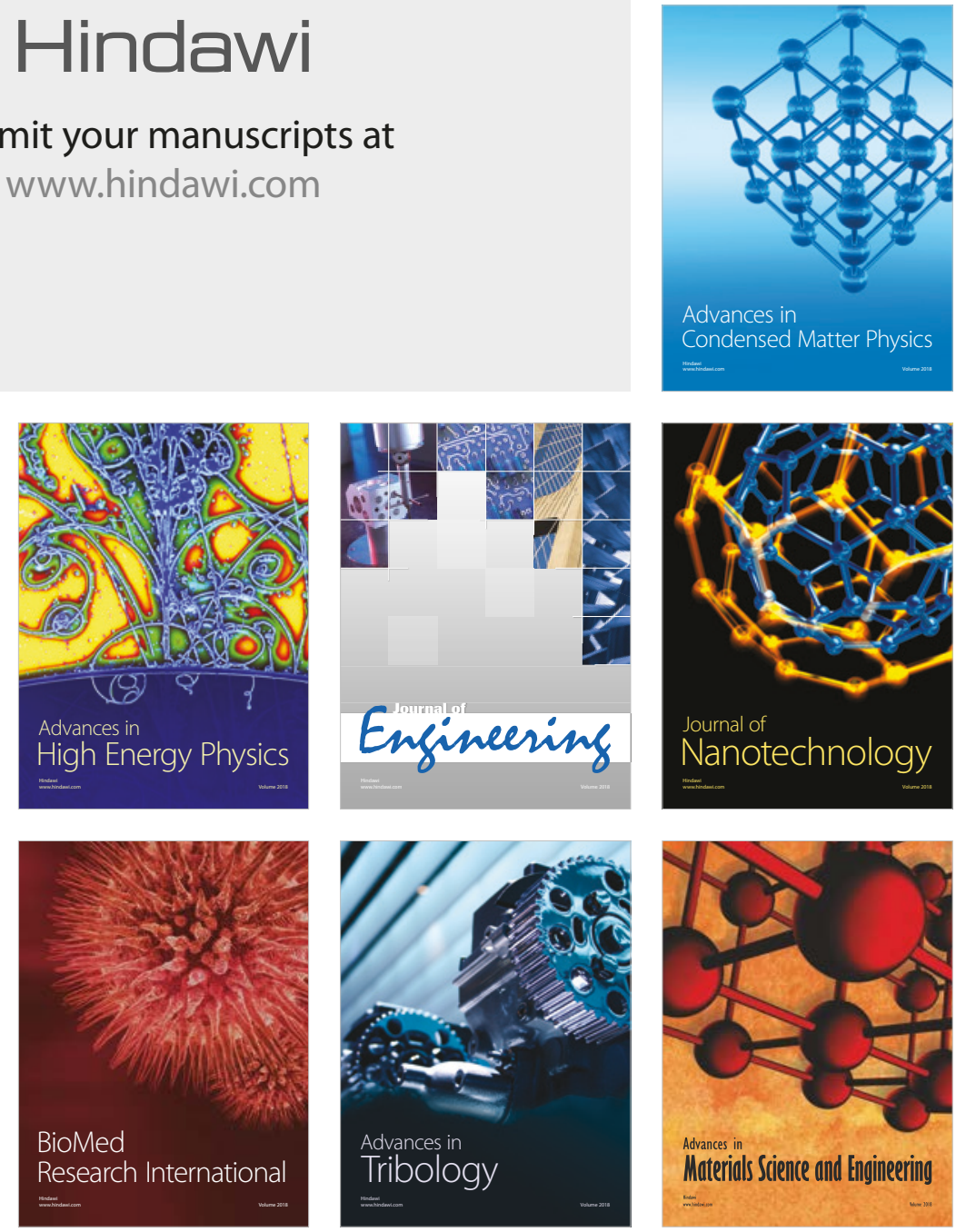